\title{
ASSESSMENT OF PHYSICOCHEMICAL CHARACTERSTICS OF DRINKING WATER SOURCES IN CHAWMANU R.D. BLOCK OF DHALAI DISTRICT, TRIPURA, INDIA
}

\author{
Mihir Kumar Das ${ }^{1}$, Bishu Karmakar ${ }^{2}$, Rajib Paul ${ }^{3}$, Rahul Lodh ${ }^{4}$ \\ ${ }^{I}$ Scientist 'C', Tripura State Pollution Control Board, Parivesh Bhawan, Gurkha Basti, Agartala, Tripura, India \\ ${ }^{2}$ Scientist 'B', Tripura State Pollution Control Board, Parivesh Bhawan, Gurkha Basti, Agartala, Tripura, India \\ ${ }^{3}$ JSA, Tripura State Pollution Control Board, Parivesh Bhawan, Gurkha Basti, Agartala, Tripura, India \\ ${ }^{4} J L A$, Tripura State Pollution Control Board, Parivesh Bhawan, Gurkha Basti, Agartala, Tripura, India
}

\begin{abstract}
Assessment of physicochemical characteristics of drinking water have numerous and severe implication for public health. Ground water as well as the stream water is the main source of drinking water in rural area of Chawmanu R.D. Block, Tripura, India. In the present study water is collected from different locations of 3 Gaon Panchayat of the said area. Physicochemical parameters are analysed in March, 2014. Results of the study reveals the fact that the water sources are very much polluted and is not suitable for drinking. Almost in all of the locations, Turbidity (TU), BOD, COD and iron value is found above the standard limit according to BIS. To overcome such problems Government authority as well as other public organization should come forward to cope up this problem and provided safe drinking water for the rural residents of Tripura state particularly at Chawmanu.
\end{abstract}

Keywords: Physicochemical, drinking water, Iron, Chawmanu, Tripura.

$* * *$

\section{INTRODUCTION}

Access to the reliable source of safe water is essential for the sustainable development which is depends upon the chemical and physical characteristics of water [1]. Ground water is the main source of drinking water in both rural and urban areas along with supply of water for agriculture and industrial needs [2-3]. Presently more than 1 billion people worldwide are lacking to the access of safe drinking water [4]. Same is true for the Tripura state where 330 habitations are still uncovered for purified potable water sources, in addition with no good health care facilities in more than 1276 distant location of the state. Therefore hill people, who live in remote rural areas, are suffering from water crisis due to drying up of regular water sources during dry season. As a result they are compelled to use contaminated water sources (streams/hand-dug well, ring well etc.) for drinking and domestic purposes, that consequently leads to the breakout of water borne diseases like typhoid, diarrhoea etc. As a consequence the quality of drinking water sources is a vital concern because of its limited availability for human welfare [5]. Though water cycle is a dynamic system quality of fresh water is mainly controlled by natural as well as anthropogenic factors $[1,6]$. The physicochemical contaminants that adversely degrade the water quality is from a variety of sources, including land application of agricultural chemicals and organic wastes, infiltration of irrigation water, septic tanks and infiltration of effluent from sewage treatment plants, pits, lagoons and ponds used for storage [7]. So the quality of potable water from various sources is likely to change on temporal and spatial basis and the change in the natural equilibrium restrains the usefulness of the water for its designated use [5]. In recent times because of rapid urbanization and growth of population, an enormous demand for fresh water is raising day by day in developing countries like India. Due to the massive needs of freshwater both in rural and urban areas for domestic and industrial purposes, it is essential that its quality should be maintained [8], specially for the state of Tripura where the people of rural areas are greatly depended upon the underground water, stream water or other surface water sources for drinking and other domestic purposes. So, it is become crucial to monitor the quality of water which is used for drinking and domestic purposes and also to find out the remedial measures to protect freshwater sources. Because, whenever the fresh water sources are infected their quality cannot be renovated by stopping the pollutants from the source [9-12].

The present study was focused to asses the physicochemical characteristics of drinking water sources viz. hand-dug well, ring well and stream water, of the Chawmanu R.D. Block of Dhalai district of Tripura state. Because of limited study very little is known about the physicochemical characteristics of water resources of Tripura. Regular study of water quality monitoring may be considered as reference for the society to get cautious about the coming decline of their environmental health. So from the health point of view the water quality of this state should be assessed scientifically and continuous monitoring of the water quality might be helpful to contrivance ways to protect the drinking water sources of the state [13]. 


\section{MATERIALS AND METHODS}

Water samples were collected during the month of March, 2014 (dry season) from different locations of the Chawmanu R.D. Block. For this purpose a reconnaissance survey was conducted in the block to identified water sources viz. handdug wells, ring wells and hilly streams to collect sample, which has been exclusively used as a main water source for drinking and domestic purposes. Physicochemical characteristics of water samples are analysed for 14 standard parameters.

\subsection{Study Area}

Chawmanu R.D. Block lies between latitude $23^{\circ} 51^{\prime} 07.91 " \mathrm{~N}$ and longitude $91^{\circ} 59^{\prime} .35 .53^{\prime \prime}$ is located in the Dhalai district of Tripura state, India. The study area comprised of 17 different locations of the Block spreading in 3 Gaon Panchayat namely, Manik Pur Gaon Pachayat (MPGP), Makar Cherra Gaon Panchayat (MCGP) and Purba Chawmanu Gaon Panchayat (PCGP). Study areas are selected on the basis of population or by intensity of water use. 10 sampling locations were fixed up for sampling in MPGP (Table 1), where 5 ring wells, a hand-dug well and 4 streams were considered for sampling. Whereas, 4 sampling locations in MCGP ( 2 hand-dug wells, a ring well and a stream) and 3 sampling locations in PCGP (2 ring wells and a hand-dug well) was selected. Details of sampling sites with particular name of sampling location, source of water etc. are presented in Table 1.

\subsection{Sample Collection}

Samples are collected in cleaned plastic polyethylene bottles and brought to the laboratory in an icebox jar to avoid unusual change in water quality. All the samples were collected during the extreme hours of water extraction by the local peoples. Prior to the sampling all the bottles are washed and rinsed thoroughly with distilled water. Standard methods [14] were followed for sample collection and preservation.

\subsection{Analysis}

Each of the collected water samples are analysed for 14 physicochemical parameters followed by standard methodologies by [14], which includes 4 physical and 10 chemical parameters viz. $\mathrm{pH}$, turbidity (TU), Electrical conductivity (EC), total dissolve solids (TDS), dissolve oxygen (DO), biological oxygen demand (BOD), chemical oxygen demand (COD), alkalinity (AL), total hardness (TH), calcium $\left(\mathrm{Ca}^{+2}\right)$, magnesium $\left(\mathrm{Mg}^{+2}\right)$, iron $(\mathrm{Fe})$, sulphate $\left(\mathrm{SO}_{4}\right)$ and chloride $\left(\mathrm{Cl}^{-}\right)$.

\section{RESULTS AND DISCUSSION}

The results of physicochemical parameters obtained from water samples collected from different sites of studied area are presented in Table.2. The results of the samples collected from different sites vary with different values because of the different nature of soil contamination [15]. Studied ground water sources (ring well and hand-dug well) are devoid of any covering which allows the surface runoff into the wells and also direct contamination of various polluting agents. Results of the physicochemical parameters obtained from this study are discussed bellow-

\section{$3.1 \mathrm{pH}$}

The $\mathrm{pH}$ is a measure of free hydrogen ion and hydroxyl ions which maintain acidic and basic property in the water system. $\mathrm{pH}$ is an important indicator of water which is altering chemically because it can be affected by chemicals in the water [16]. The standard value of $\mathrm{pH}$ for drinking is 6.5- 8.5 according to BIS. In this study highest value of $\mathrm{pH}$ is measured 9.01 in $\mathrm{KK} 2$ (S16), from source hand-dug well whereas, the lowest value of is measured 6.00 in MP (S2), from source ring well (Table. 2). The result of $\mathrm{pH}$ for all water samples however, is agreement with the range given in BIS except in MP, MPUC2 and KK2.

\subsection{Turbidity (TU)}

TU is the optical property of water by which light is scattered due to colloidal and extremely fine dispersion [16]. TU in drinking-water may be due to the presence of inorganic particulate matter in some groundwater or sloughing of bio film within the distribution system [17]. TU of the studied samples is measured by the Hanna Turbidity meter and is recorded between minimum $10 \mathrm{NTU}$ in MPUC2 (S5) to maximum 86 NTU in AMKP1 (S11). Obtained turbidity is very high in all the studied ground water and found above the limits prescribed by BIS (1050091) which is 5 NTU.

\subsection{Electrical conductivity (EC) and Total Dissolve Solids (TDS)}

EC is the measure of the ability of an aqueous solution to convey an electric current which is used an indicator of total concentration of ion in water solution [18]. There is a high degree of correlation between EC and TDS as both signify the amount of dissolved solid [19]. The highest value of EC (265 $\mu \mathrm{mho} / \mathrm{cm})$ is obtained at HPKP (S13) from hand-dug well whereas the lowest value $(89 \mu \mathrm{mho} / \mathrm{cm})$ is obtained at RDC1 (S8) from stream. Total dissolved solids is the measure of constitute concentration which indicate the salinity behaviour of groundwater. Water containing more than $500 \mathrm{mg} / \mathrm{L}$ of TDS is not considered desirable for drinking water supplies, but in unavoidable cases $1500 \mathrm{mg} / \mathrm{L}$ is also allowed [20]. TDS of the studied samples are found to be in the range ( 70 to $170 \mathrm{mg} / \mathrm{lit}$ ).

\subsection{Dissolve Oxygen (DO)}

DO is measure of dissolve oxygen it the water which play an important role in water quality monitoring. DO is important because it is absolutely essential for the survival of aquatic organisms and also affects a vast number of other parameters. Not only the physicochemical parameters but aesthetic ones like the odour, clarity and taste. Consequently, oxygen is perhaps the most important and established indicator of water quality. Contamination of 
sewage water and organic waste consumes oxygen and is often concentrated in summer. Precise monitoring of DO is essential for documenting changes to the environment caused by natural phenomena as well as human activities. Many chemical and biological reactions in ground water and surface water depend directly or indirectly on the amount of oxygen present.

In this study DO is measured between $1.02 \mathrm{mg} / \mathrm{lit}$ to 6.05 $\mathrm{mg} / \mathrm{lit}$. Water samples from groundwater sources are found relatively low in concentration except few locations (HPKP, KK2 and KK3. Surface water sources are found to be high concentration of DO except two location (RDC1 and KMRP) where DO is found $2.24 \mathrm{mg} / \mathrm{lit}$ and $1.66 \mathrm{mg} / \mathrm{lit}$ respectively.

\subsection{Biological Oxygen Demand (BOD)}

BOD measures the quantity of oxygen consumption by microorganisms during decomposition of organic matter [21]. Though it is not a precise quantitative test, it is widely used as an indicator of organic quality of water [22]. The high BOD may indicate fecal and organic waste contamination from human and animal sources and restricts the use of water for drinking and domestic use. An increase BOD asserts a potential health threat to the people those who are using the water with high BOD for drinking. Thus it is important to monitor BOD to identify areas posing a threat to health, to identify sources of contamination and ensure adequate action for remedial measures.

In this study BOD is found high in almost the entire studied sample which is measured between 0.28 to $14.25 \mathrm{mg} / \mathrm{l}$. . BOD level of water samples collected from HPKP, KK3 are only found within standard level otherwise all are ahead of margins.

\subsection{Chemical Oxygen Demand (COD)}

COD determines indirect measure of the amount of organic compounds present in water. This is a very good indicator of water quality and a check commonly used by Municipalities and governing bodies to assess water quality. High COD may be a consequence of sewage contamination. Dissolve oxygen is consumed in the oxidation-reduction reactions of introduced compounds such as nitrate $\left(\mathrm{NO}_{3}{ }^{{ }^{-}}\right)$, ammonium $\left(\mathrm{NH}_{4}{ }^{1+}\right)$, sulphate $\left(\mathrm{SO}_{4}{ }^{-2}\right)$, sulphite $\left(\mathrm{SO}_{3}{ }^{{ }^{-}}\right)$, ferrous $\left(\mathrm{Fe}^{2+}\right)$ and ferric $\left(\mathrm{Fe}^{3+}\right)$ ions. In this study we observed only sulphate and ferrous ion concentration as because high iron concentration in ground water is reported here in Tripura [13].

COD value is found high in all of the studied samples which are measured between minimum $12 \mathrm{mg} / \mathrm{l}$ in $\mathrm{KK} 3$ and maximum $41 \mathrm{mg} / \mathrm{l}$ in KMRP.

\subsection{Alkalinity (AL)}

Alkalinity of the water has the capacity to neutralize the strong acids due to presence of carbonate, bicarbonate compounds of calcium, magnesium etc. [20]. It is expressed in terms of parts per million or $\mathrm{mg} / \mathrm{litre}$. Total alkalinity values for the investigated samples were found to be within the BIS limits of $250 \mathrm{mg} / \mathrm{l}$ except KMP (264.37 mg/lit).

\subsection{Total Hardness (TH)}

Hardness is the property of water which prevents the lather formation with soap by formation of complex with calcium, magnesium present on water [20]. So hardness depends upon calcium or magnesium or both. The water quality analysis shows that all water samples were within permissible limit for total hardness where maximum is found at MPUC1 (169.32 mg/lit) and minimum at MPUC2 (39.61 mg/lit).

\subsection{Calcium $\left(\mathrm{Ca}^{+2}\right)$ and Magnesium $\left(\mathrm{Mg}^{+2}\right)$}

Multivalent cations, particularly calcium and magnesium are often present at a considerable concentration in natural waters as a carbonates and bicarbonates and are directly related to hardness [23]. Insufficient amount of calcium may induce adverse physiological effects as well as excess amount of calcium in body results in formation of urinary bladder stone and irritation in urinary passage. The Calcium concentration in water of the study area ranged between 3.97 to $51.59 \mathrm{mg} / \mathrm{l}$. which was found within the BIS limit of 75 $\mathrm{mg} / \mathrm{lit}$.On the other hand Magnesium acts as an activator of many enzyme systems. Magnesium is an important component of basic igneous, volcanic and metamorphic and sedimentary rocks. The high concentration of magnesium ion may cause laxative effect, while deficiency may cause structural and functional changes. The concentration of magnesium ion measured between 1.21 to $21.65 \mathrm{mg} / \mathrm{l}$. and was found within the limit prescribed by BIS. [24]

\subsection{Iron $\left(\mathrm{Fe}^{2+}\right)$}

The main sources of iron in natural water are as a mineral from sediment and rocks or from mining, industrial waste and oxidize metal. It is present in ground water at very low concentration as ferrous bicarbonate, Ferric hydroxide, organic complex iron or corrosion product such as $\mathrm{Fe}_{3} \mathrm{O}_{4}$. But in Tripura condition iron concentration is reports as high as $28.55 \mathrm{mg} / \mathrm{l}$ [13]. Iron is essential metal to all organisms and present in haemoglobin system. The high concentration causes a harsh taste to water and a brownish colour to sluice clothing. The shortage of iron causes a disease called anaemia and continues consumption of drinking water with high concentration of iron for a long time can lead to liver disease called as haermosiderosis [25-26]. The entire sample analyzed has the iron content within the tolerance limits except sample no. S3, S6, S7, S10, S11, S15 which were higher than the standard given by BIS (Table. 2) which is $0.3 \mathrm{mg} / \mathrm{lit}$.

\subsection{Sulphate $\left(\mathrm{SO}^{2}{ }^{-}\right)$}

Sulphates originate from several sources including natural as well as industrial effluents; however, naturally occur in groundwater are from leaching of natural mineral sources. Higher concentration sulphates are likely to react with 
human organs and may cause gastrointestinal irritation mainly when drinking water resources also contains $\mathrm{Mg}$ and Na. People consuming drinking water containing sulphate concentration more than $600 \mathrm{mg} / \mathrm{l}$ are also experiences Carthartic effects $[1,23]$. The sulphate concentration of the studied area varied between $6.53 \mathrm{mg} / \mathrm{L}$ and $13.07 \mathrm{mg} / \mathrm{L}$. and found within the prescribed limit of $200 \mathrm{mg} / \mathrm{lit}$ given by BIS [24].

\subsection{Chloride $\left(\mathrm{Cl}^{-}\right)$}

The concentration of chloride is the indicator of sewage pollution and also imparts laxative effect. Atmospheric sources or sea water contamination is reason for bulk of the chloride concentration in groundwater which may exceed due to base- exchange phenomena, high temperature, domestic effluents, septic tanks and low rainfall [20]. Porosity soil and permeability also plays a key role in building up the chlorides concentration [27]. The chloride content of studied water samples were within permissible limit of $250 \mathrm{mg} / \mathrm{lit}$ prescribed by BIS [24].

\section{CONCLUSIONS}

The study investigated physicochemical properties of the ground water (open ring well and hand-dug well) as well as the surface water (stream) as a main drinking water source. From the analytical result (Table-2), it was found that the water quality of studied water samples is not suitable for drinking purpose. All the samples were found highly turbid and the observed values are beyond standard value prescribed by BIS. High turbidity of water samples suggested that water sources are contaminated by inorganic particulate materials. High BOD of almost all studied samples indicates fecal contamination in the water which is very unsafe for health point of view which may lead fatal breakout of water born diseases. Along with high BOD, COD also found very high in all of the studied locations. High COD is found might be due to high concentration of iron present in the soil of the state. Amount of Iron in seven locations at chawmanu is found higher than the standard value. All the studied ground water was found open during sample collection. All the ground water sources which are visited for this study purpose were found open. As all the sources have the direct access, rate of contamination gets high during monsoon period as well as due to human activities. Surrounding surface runoff directly discharged into the dug wells which cause degradation of the ground water quality.

So, from this study it may be concluded the water sources of chawmanu R.D block are not at al safe for drinking and domestic function .Particularly in the state like Tripura were the health care facilities are not so good, drinking of contaminated water could cause serious health problem. To resolve such problems government should assign local authorities for proper remedial action to restore proper water quality as early as possible to provide safe drinking water to the rural residents of Tripura state.

\section{ACKNOWLEDGMENTS}

The authors are cordially thankful to the Chairman, Tripura State Pollution control Board for his continuous support and encouragement throughout the study. Thanks are also due to Member Secretary, Tripura State Pollution Control Board for providing laboratory facilities to accomplish the analysis. Last but not the least we are very much grateful to all the staffs of Tripura State Pollution Control Board for their all time moral support during the study.

\section{REFERENCES}

[1] P. J. Sajil Kumar and E. J. James, (2013) “ Physicochemical parameters and their sources in groundwater in Thirupathur region, Tamilnadu, South India,"Appl. Water Sci. Vol.3, pp- 219-228.

[2] D. Gupta, P. Sunita and J. P. Saharan., (2009). Researcher., 1(2),1-5.

[3] Y. A. Maruthi, K. Hossain and A. Goswami, Der Chemica Sinica., (2012), vol.3(5), pp-1071-1074.

[4] Peeler K.A, Opsahl S.P and chantan J.P., (2006), "Tracking anthropogenic inputs using caffeine, indicator bacteria and nutrients in rural freshwater and urban marine systems," Environ. Sci. Technol., vol. 40,pp- 7616-7622 .

[5] Sehar Shama, Iffat Naz, Mohammad Ishtiaq Ali and Safia Ahmed., (2011), "Monitoring of PhysicoChemical and Microbiological Analysis of Under Ground Water Samples of District Kallar Syedan, Rawalpindi-Pakistan," Research Journal of Chemical Sciences, Vol. 1(8), pp- 24-30.

[6] P.B. Nagarnaik, Mr. Pankaj N. Patilo,(2012), "Analysis of ground water of rural areas of wardha city using physico-chemical and Biological parameters," International Journal of Engineering Research and Applications, vol.2, issue 3, pp-803807.

[7] H. Pathak (2012), "Assessment of physico-chemical quality of groundwater by multivariate analysis in some populated villages nearby sagar city, M.P, India," J. Environ. Anal. Toxicol, vol. 2, issue5, 144.

[8] Yerramsetty Abbulu, G.V.R. Srinivasa Rao., (2013), "A study on physic-chemical characteristics of ground water in the industrial zone of Visakhapatnam, Andhra Pradesh," American Journal of Engineering Research, vol.2, issue.10, pp-112116.

[9] D. G. Shah and P. S. Patel, Der Chemica Sinica, 2(5), 8-11(2011).

[10] R. K. Trivedy and P. K. Goel., Chemical and Biological Methods for Water Pollution Studies, Environmental Publication, India, 1986

[11] S. Hooda, S. Kaur, (1999), Cited in Laboratory Manual for Environmental Chemistry, Edited by S.Chand \& Company Limited, Ram Nagar, New Delhi,

[12] S.C. Hiremath, M.S. Yadawe, U.S. Pujeri, D.M. Hiremath $^{2}$ and A.S. Pujar, (2011), Current World Environment. 6(2), 265-269

[13] Paul Supantha, Mishra Umesh,(2011), “Assessment of underground water quality in North Eastern region of India: A case study of Agartala City", 
International Journal Of Environmental Sciences,vol. 2, No 2, , pp-850-862.

[14] APHA, 2005. Standard methods for the examination of water and waste water (21st ed.), Washington, D.C: American Public Health Association.

[15] A.I Vogel, (1978), "Text Book of Quantitative Inorganic Analysis", $4^{\text {th }}$ edition, ELBS, London.

[16] J.G. Gichuki, J.M. Gichumbi, (2012), "PhysicoChemical Analysis of Ground Water fromKihara Division, Kiambu County, Kenya”, Journal of Chemical, Biological and Physical Sciences, Vol. 2, No. 4, pp-2193-2200

[17] Emmanuel Bernard, Nurudeen Ayeni.,(2012), "Physicochemical Analysis of Ground Water samples of Bichi local government area of kano state of Nigeria," ARPN Journal of Science and Technology, vol. 2, Special Issue, pp-325-332

[18] M. Banar, O. Aysun, and K. Mine, (2006), "Characterization of the leachate in an urban landfill by physicochemical analysis and solid phase microextraction. GC/MS," Environ. Monitor. Assess., 121, pp-439-459.

[19] J. Husain, K.C. Sharma, I. Husain, K.G. Ojha, and V.K. Vaidya, (2001), "Physico-chemical characteristics of water from bore wells of an industrial town Bhilwara, Rajasthan: a correlation study," Asian J Chem,vol.13, pp-509-512.

[20] B. Venkateswara Rao, (2011), "Physicochemical analysis of selected ground water samples of Vijayawada rural and urban in Krishna district, Andhra Pradesh, India," International Journal of Environmental Sciences, vol. 2, No 2, pp-710-714.
[21] R. Lodh, R. Paul, B. Karmakar and M.K. Das, (2014), "Physicochemical studies of water quality with special reference to ancient lakes of Udaipur City, Tripura, India," International Journal of Scientific and Research Publications, Volume 4, Issue 6.

[22] N. C. Sawyer, L. P. McCarty, G. F. Parkin, (2003). "Chemistry for Environmental Engineering and Science (5th ed.)". New York: McGraw-Hill. ISBN 0-07-248066-1.

[23] R. K. Dubey, Jakir Hussain, Nishchay Malhotra, Ankur Mehta, (2014), “Ground Water Quality And Water Quality Index Of Dwarka District Of National Capital Of India," International Journal of Research in Engineering and Technology, Volume: 03, Issue: 04, pp 2321-7308

[24] BIS, 1991. Indian Standards for Drinking Water, Bureau of Indian Standards, New Delhi, IS: 10500.

[25] B. Behera, M. Das and G. S. Rana, (2012), "Studies on ground water pollution due to iron content and water quality in and around, Jagdalpur, Bastar district, Chattisgarh, India," Journal of Chemical and Pharmaceutical Research, vol- 4(8), pp-3803-3807

[26] N.C. Das, (2013), "Physico-Chemical Characteristics of Selected Ground Water Samples of Ballarpur City of Chandrapur District, Maharashtra, India," International Research Journal of Environment Sciences, Vol. 2(11), pp- 96-100.

[27] D. K. Chanda, (1999), Hydrology Journal, 7(5), pp 431439

Table-1 Details of the study locations of sample collection

\begin{tabular}{|c|c|c|c|c|}
\hline $\begin{array}{l}\text { NAME OF THE } \\
\text { R.D. BLOCK }\end{array}$ & $\begin{array}{l}\text { NAME OF THE } \\
\text { PANCHAYAT }\end{array}$ & $\begin{array}{lll}\text { NAME } & \text { OF } & \text { THE } \\
\text { VILLAGE } & & \end{array}$ & $\begin{array}{l}\text { SOURCE } \\
\text { OF } \\
\text { WATER }\end{array}$ & $\begin{array}{l}\text { SAMPLE } \\
\text { ID }\end{array}$ \\
\hline \multirow{13}{*}{ CHAWMANU } & \multirow{10}{*}{$\begin{array}{l}\text { Manik Pur Gaon } \\
\text { Panchayat (MPGP) }\end{array}$} & $\begin{array}{l}\text { Juri Kumar Roaja Para } \\
\text { (JKRP) }\end{array}$ & Ring well & $\mathrm{S} 1$ \\
\hline & & Manik Pur (MP) & Ring well & $\mathrm{S} 2$ \\
\hline & & Kumaaria Para (KP) & Ring well & S3 \\
\hline & & $\begin{array}{l}\text { Manik Pur Upanagar } \\
\text { Colony1 (MPUC1) }\end{array}$ & Ring well & $\mathrm{S} 4$ \\
\hline & & $\begin{array}{l}\text { Manik Pur Upanagar } \\
\text { Colony2 (MPUC2) }\end{array}$ & Dug well & S5 \\
\hline & & $\begin{array}{l}\text { Padma Singh Roaja Para } \\
\text { (PSRP) }\end{array}$ & Ring well & S6 \\
\hline & & $\begin{array}{lll}\begin{array}{l}\text { Manida } \\
(\mathrm{MRP})\end{array} & \text { Roaja } & \text { Para } \\
\end{array}$ & Stream & S7 \\
\hline & & $\begin{array}{l}\text { Raj Dhar Cherral } \\
\text { (RDC1) }\end{array}$ & Stream & S8 \\
\hline & & $\begin{array}{l}\text { Raj Dhar Cherra2 } \\
\text { (RDC2) }\end{array}$ & Stream & S9 \\
\hline & & Haza Cherra (HC) & Stream & S10 \\
\hline & \multirow{3}{*}{ 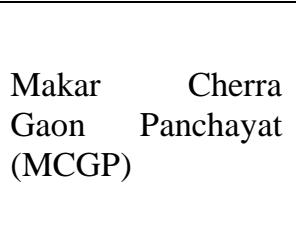 } & $\begin{array}{l}\text { Arjun Mani Karbari } \\
\text { Para1 (AMKP1) }\end{array}$ & Ring well & S11 \\
\hline & & 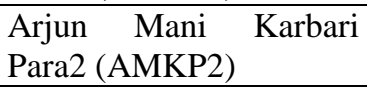 & Dug well & S12 \\
\hline & & $\begin{array}{l}\text { Halam Pha Karbari Para } \\
\text { (HPKP) }\end{array}$ & Dug well & S13 \\
\hline
\end{tabular}




\begin{tabular}{|l|l|lr|l|l|}
\hline & \multicolumn{2}{|l|}{$\begin{array}{l}\text { Kalpa Mohan Roaja para } \\
\text { (KMP) }\end{array}$} & Stream & S14 \\
\cline { 2 - 6 } & $\begin{array}{l}\text { Khakchang Kami1 } \\
\text { Purba Chawmanu }\end{array}$ & Ring well & S15 \\
\cline { 2 - 6 } $\begin{array}{l}\text { Gaon Panchayat } \\
\text { (PCGP) }\end{array}$ & $\begin{array}{l}\text { Khakchang } \\
\text { (KK2) }\end{array}$ & $\begin{array}{l}\text { Khakchang } \\
\text { (KK3) }\end{array}$ & Kami3 & Ring well & S17 \\
\hline
\end{tabular}

Table-2 Result of the Physicochemical Analysis of the Water Sample of Chawmanu R.D. Block

\begin{tabular}{|c|c|c|c|c|c|c|c|c|c|c|c|c|c|c|}
\hline $\begin{array}{l}\text { Sam } \\
\text { ple } \\
\text { ID }\end{array}$ & $\mathrm{pH}$ & $\begin{array}{l}\text { TU } \\
\text { (NTU) }\end{array}$ & $\begin{array}{l}\text { EC } \\
(\mu \\
\mathrm{mho} / \mathrm{c} \\
\mathrm{m}) \\
\end{array}$ & $\begin{array}{l}\text { TDS } \\
\text { (mg/ } \\
\text { 1) }\end{array}$ & $\begin{array}{l}\text { DO } \\
\text { (mg/ } \\
\text { l) }\end{array}$ & $\begin{array}{l}\text { BOD } \\
\text { (mg/l } \\
)\end{array}$ & $\begin{array}{l}\text { COD } \\
(\mathrm{mg} / \mathrm{l} \\
)\end{array}$ & $\begin{array}{l}\mathrm{AL} \\
(\mathrm{mg} / \mathrm{l})\end{array}$ & $\begin{array}{l}\mathrm{TH} \\
(\mathrm{mg} / \mathrm{l})\end{array}$ & $\begin{array}{l}\mathrm{Ca} \\
(\mathrm{mg} / \mathrm{l} \\
)\end{array}$ & $\begin{array}{l}\mathrm{Mg} \\
(\mathrm{mg} / \mathrm{l} \\
)\end{array}$ & $\begin{array}{l}\mathrm{Fe}^{2+} \\
(\mathrm{mg} / \mathrm{l} \\
)\end{array}$ & $\begin{array}{l}\mathrm{SO}_{4}{ }^{2} \\
(\mathrm{mg} / 1 \\
)\end{array}$ & $\begin{array}{l}\mathrm{Cl} \\
(\mathrm{mg} / \mathrm{l} \\
)\end{array}$ \\
\hline S1 & 6.91 & 14 & 95 & 142 & 2.19 & 10.30 & 22 & 125.60 & 108.91 & 25.80 & 10.83 & 1.70 & 11.22 & 9.81 \\
\hline S2 & 6.00 & 25 & 180 & 108 & 1.66 & 5.60 & 26 & 65.01 & 59.41 & 7.94 & 9.62 & 0.13 & 12.24 & 26.95 \\
\hline S3 & 7.77 & 18 & 120 & 136 & 1.32 & 7.50 & 31 & 130.02 & 99.01 & 19.84 & 12.03 & 1.63 & 10.00 & 7.35 \\
\hline S4 & 7.44 & 34 & 190 & 102 & 1.02 & 6.10 & 27 & 190.69 & 169.32 & 45.64 & 13.24 & 0.15 & 9.18 & 24.51 \\
\hline S5 & 6.17 & 10 & 222 & 70 & 1.56 & 6.23 & 24 & 30.34 & 39.61 & 3.97 & 7.22 & 0.23 & 6.53 & 19.61 \\
\hline S6 & 7.46 & 19 & 210 & 102 & 1.80 & 15.10 & 19 & 134.35 & 168.32 & 47.62 & 12.03 & 0.97 & 10.82 & 29.40 \\
\hline S7 & 6.99 & 43 & 136 & 164 & 5.94 & 9.56 & 32 & 47.67 & 69.31 & 13.89 & 8.42 & 0.74 & 13.07 & 9.81 \\
\hline S8 & 7.17 & 26 & 89 & 136 & 2.24 & 14.25 & 18 & 78.01 & 108.91 & 15.87 & 16.84 & 0.28 & 6.94 & 14.70 \\
\hline S9 & 7.04 & 30 & 168 & 116 & 6.05 & 11.50 & 21 & 78.01 & 99.01 & 15.87 & 14.43 & 0.13 & 7.76 & 14.70 \\
\hline S10 & 6.99 & 43 & 136 & 164 & 5.94 & 9.56 & 32 & 47.67 & 69.31 & 13.89 & 8.42 & 0.74 & 13.06 & 9.81 \\
\hline S11 & 7.47 & 86 & 230 & 112 & 3.46 & 8.52 & 15 & 112.68 & 168.32 & 31.57 & 21.65 & 0.46 & 12.04 & 34.30 \\
\hline S12 & 7.75 & 46 & 138 & 152 & 3.66 & 7.80 & 16 & 160.36 & 59.41 & 15.87 & 4.81 & 0.10 & 6.94 & 9.81 \\
\hline S13 & 6.84 & 20 & 265 & 90 & 5.17 & 0.28 & 29 & 47.67 & 69.51 & 19.72 & 4.88 & 0.06 & 12.84 & 12.25 \\
\hline S14 & 7.27 & 51 & 121 & 170 & 1.66 & 8.17 & 41 & 264.37 & 168.32 & 51.59 & 9.63 & 0.22 & 11.22 & 9.81 \\
\hline $\mathbf{S 1 5}$ & 8.50 & 29 & 180 & 132 & 2.45 & 4.70 & 27 & 78.01 & 69.31 & 25.80 & 1.21 & 0.38 & 11.02 & 14.70 \\
\hline S16 & 9.01 & 51 & 230 & 148 & 5.56 & 4.50 & 14 & 91.01 & 89.11 & 23.81 & 7.22 & 0.20 & 8.16 & 12.25 \\
\hline S17 & 7.60 & 74 & 110 & 110 & 5.95 & 2.10 & 12 & 69.34 & 89.11 & 15.87 & 12.03 & 0.14 & 8.98 & 7.95 \\
\hline
\end{tabular}

